To Cite This Article: Güçlü, Y. (2020). Changes in summer and tropical days at the lakes district of the Mediterranean region of Turkey between the period of 1969-2014. International Journal of Geography and Geography Education (IGGE), 42, 631-649.

\title{
CHANGES IN SUMMER AND TROPICAL DAYS AT THE LAKES DISTRICT OF THE MEDITERRANEAN REGION OF TURKEY BETWEEN THE PERIOD OF 1969-2014
}

Yüksel GÜÇı̈̈1

\begin{abstract}
Summer and tropical days are determined about the daily maximum air temperature values. Examining the annual numbers of summer and tropical days is one of the methods to reveal changes and trends in air temperatures and therefore in climate on a global, regional and local scale. This study aims to examine the long-term changes and trends of the annual numbers of summer and tropical days of the Lakes District of Turkey, which is located in the transition zone between Mediterranean climate and Central Anatolia continental climate between the period of 1969-2014 at 11 meteorological stations. Singular scanning method was used in the study. The results suggest that the numbers of summer and tropical days changed within the years of the period examined. In the analyzed period, it has been determined that the annual numbers of summer and tropical days and the annual numbers of tropical days change within years and periods, and show an increase, and trend lines also indicate an increase. It was determined that the number of tropical days showed a significant increase trend in all stations and in the average of the study area. Also, it has been determined that the annual numbers of summer days generally decrease over the years and periods and the trend lines also indicate a decrease. The number of summer days shows a decreasing trend that is not significant in Beyşehir, Eğirdir and Uluborlu stations, but significant in other stations and in the average of the study area. The increasing trend in tropical days can be considered as a potential risk for human health and activities and natural environment.
\end{abstract}

Keywords: Tropical Day, Summer Day, Climatic Change, The Lakes District of Turkey, Eastern Mediterranean 


\section{INTRODUCTION}

As it is known, the processes occurring in the atmosphere, which is one of the most important elements in the system of the Earth, create weather events and climate. The most important factor that forms the weather events and climate is air temperature (Dönmez, 1984). Depending on the shape and movements of the Earth and geographical factors, instant, daily, seasonal and long-term changes in air temperatures can be seen on a global and local scale.

The changes in air temperature have important effects on living and inanimate environmental components on Earth. Especially the effects of extreme air temperatures are very important. For this reason, since the second half of the 19th century, when meteorological data was started to be recorded, scientific researches on air temperature on a global and local scale increased rapidly. Among the most researched topics in this process, revealing long-term and simultaneous conditions and changes in air temperatures and evaluating extreme air temperatures have taken an important place. The number of scientific research on this subject has increased rapidly since the last quarter of the 20th century. These research studies have created important literature over time. For example, it is stated that the number of publications on climate change has been going up since the 1980s (IPCC, 2014).

Global research dealing with different aspects of the change in air temperatures and climate include Lafta and Lorenzen (1995), Adams et al., (1998), Klein Tank and Können (2003), Alexander et al., (2006), Christensen and Christensen (2007), Kang et al., (2009), Hansen et al., (2010), Zhang et al., (2011), Hatfield and Prueger (2015), Caloiero (2017) can be counted. Research on the Mediterranean basin on this subject can be given as examples of the research of ArseniPapadimitriou and Maheras (1991), Xoplaki et al. (2003), Kostopoulou and Jones (2005), Diffenbaugh et al. (2007), Alpert et al. (2008), Giorgi and Lionello (2008), Hertig et al. (2010), Kuglitsch et al. (2010), Simolo et al. (2014). Research on Turkey on the change in air temperatures and climate can be given as examples of the research of Türkeş (1995), Türkeş et al. (1995), Türkeş et al. (1996), Kadıoğlu (1997), Çiçek (2000), Kadioğlu et al. (2001), Türkeş et al. (2002), Türkeş and Sümer (2004); Acar Deniz and Türkeş (2011), Toros (2012), Karabulut (2012), Acar Deniz (2013), Acar Deniz and Gönençgil (2015), Dogan et al. (2015), Sütgibi (2015), Gönençgil and Acar Deniz (2016) and Bayer Altın and Barak (2017).

The Intergovernmental Panel on Climate Change (IPCC) is established by the World Meteorological Organization (WMO) and the United Nations Environment Program (UNEP) to address the issue of climate change, which also includes changes in air temperature on a global and local scale. Within this unit, the process is constantly being monitored, predictions related to the emerging situation and future is put forward, information is provided to partners about the precautions to be taken, and recommendations are made. The first report titled Climate Change, issued among the reports of the Intergovernmental Panel on Climate Change (IPCC) was published in 1990 (IPCC, 2014). Especially after the 1980s, attention is drawn to the increase in air temperatures worldwide. In this context, evaluations regarding heat waves that cause the death of many people in a short time have an important place. For example, in the "Climate Change Third Assessment Report" (AR3) published in 2001, the same unit highlighted the decrease in the incidence of extremely low temperatures and the increase in the incidence of extremely high temperatures (Kadıoğlu, 2012).

In the last 30-40 years, evaluations have been made regarding that extreme air temperatures have led to an increase in human mortality in some zones, while in some regions increased air temperatures have led to a decrease in coldrelated deaths (IPCC, 2014). On the other hand, the emphasis is placed on assessments regarding the possible effects of the increase in air temperatures on issues such as human health, air quality, vegetation efficiency, phenology, hydrological systems, water resources and forest fires (Lafta and Lorenzen, 1995; Adams et al., 1998; Kang et al., 2009; Erlat and Türkeş, 2013; Türkeş and Altan, 2013; Hatfield and Prueger, 2015).

As mentioned above, intensive research is being conducted on the change in air temperatures and climate at a global, regional, and local scale. In this context, one of the methods to reveal the change in air temperatures and climate is to examine the long-term change in the number of summer and tropical days. The day when the maximum daily air temperature is between $25^{\circ} \mathrm{C}$ and $30^{\circ} \mathrm{C}$ is called summer day (Erinç, 1984; Erol, 1988; Erlat and Yavaşlı, 2009, Erlat and Yavaşlı, 2011; Zhang et al., 2011; Erlat and Türkeş, 2013; Aykır, 2017). The day, in which the daily maximum air temperature exceeds $30^{\circ} \mathrm{C}$, is named as a tropical day (Erinç, 1984; Erol, 1988; Nastos and Matzarakis, 2008: 75; Erlat and Yavaşlı, 2009; Erlat and Yavaşlı, 2011; Zhang et al., 2011; Erlat and Türkeş, 2013).

Summer and tropical days considered being hot and very hot days have important effects on the natural environment, human life, and activities. For example, the increase of evaporation in summer and tropical days affects almost all living beings, especially humans, by slowing down their lives, causing them distress and creating drying effects (Erol, 1988). Especially tropical days considered to be very hot days have a negative impact on human health, especially for those who are sensitive to high air temperatures due to metabolic problems and reduces climate comfort (Nastos and 
Matzarakis, 2008). In addition, due to the increasing need for cooling these days, electricity consumption increases, the probability of forest fire is rising, drought becomes more pronounced, heavy rains and linked flooding can occur and significant losses in agricultural production may occur. One of the methods to predict, eliminates, or minimizes these incidents and a similar effect is to examine the long-term variability and trends of summer and tropical days.

As mentioned above, researches including extremely high temperatures, summer, and tropical days on a global, regional, and local scale have been conducted. However, it has been determined that research involving direct summer and tropical days are limited. In the following, the results of some of the research covering the study area and its surroundings and the period of approximately 1969-2014 are briefly mentioned.

In the studies related to the European and Mediterranean basins, it is stated that the annual number of summer days increased when the air temperatures were seen at high values in the last quarter of the 20th century (Klein Tank and Können, 2003; Xoplaki et al., 2003; Kuglitsch et al., 2010; Erlat and Türkeş, 2013). In a survey conducted by the Lelievel et al. (2012), in the Balkan Peninsula and Turkey have been found to increase the maximum air temperature values. A study in the period of 1960-2006 concluded that heatwaves increased in the Eastern Mediterranean, including Turkey (Kuglitsch et al. 2010). On the other hand, in a survey conducted by Erlat and Yavaşlı (2011), in Turkey, have been found to increase the air temperature values. In a study, it was determined that heatwaves were more severe in southwest Anatolia including the study area between 1960 and 2006 (Kuglitsch et al., 2010). In another study, it was concluded that the temperature regime changed significantly towards more temperate and warm conditions in Turkey, between 1985 and 2010, due to global warming (Türkeş, 2013). It is observed that the number of hot days in Turkey has increased since the 1990s in particular (Türkeş, 2012). Acar et al. (2018) noted an increase in the frequency of hot and extremely hot days as of 1966-2014 period. As can be seen, air temperatures in the south of Europe, the Mediterranean basin, and Turkey have generally increased as of the 1969- 2014 period. This situation indicates that global warming is experienced in these areas.

According to IPCC (2013), in parallel with the increasing air temperatures on a global scale, an increase in the annual number of summer days is observed. For example, it is stated that the annual number of summer days has risen in Europe in the last 30 years (Aykır, 2017). Erlat and Yavaşlı (2011) stated that the number of summer days increased in the southern regions of the European continent during the 1980-2010 period. In another study, particularly noted the increase in the annual number of summer days in the Eastern Mediterranean (Giannakopoulos et al., 2009). The annual number of summer days was determined to increase in researches on Turkey and covering the period of 1960- 2010 (Sensoy et al., 2008; Şensoy et al., 2013; Abbasnia and Toros, 2018). In a study covering the period 1950-2010, the annual number of summer days in Turkey has been found to show a significant upward trend after 1975 (Erlat and Türkeş, 2013). In another study, it was concluded that there was a general decrease in the annual number of summer days in Turkey (Acar Deniz, 2013). According to the results of the researches mentioned briefly southern Europe, the Mediterranean basin, and in Turkey, the annual number of summer days is usually expressed as an increase in the 1969-2014 period. However, it should be noted that the days defined as summer days in these studies generally cover tropical days. That is the days when the daily maximum air temperatures exceed $25^{\circ} \mathrm{C}$ are described as summer days, and tropical days are evaluated within the scope of summer days.

Erlat and Yavaşlı (2011) stated that the annual number of tropical days increased in the southern regions of the European continent in the period of 1980-2010. The annual number of tropical days in Greece has been determined to increase between 1976 and 2000 (Nastos and Matzarakis, 2008). Erlat and Türkeş (2013) stated that the annual number of tropical days in Turkey was determined to show a significant upward trend after 1975. In another study, it was found that the annual number of tropical days has increased significantly throughout Turkey since 1990 (Kadıoğlu, 2012). A study conducted by Acar Deniz (2013) concluded that there is a tendency towards an increase in tropical days in Turkey. Erlat and Türkeş (2017) stated that the annual number of tropical days in Turkey has reached the conclusion that demonstrates a strong upward trend after 1985. As it is seen, the annual number of tropical days in the south of Europe, the Mediterranean basin, and Turkey in the 1969-2014 period have generally increased. This suggests that global warming is clearly occurring in these areas.

It is determined that the number of annual summer and tropical days tends to increase in the Aegean Region, which is very close to the study area (Erlat and Yavaşlı, 2009). A study covering the 1939-2008 period also noted a significant increase in the annual number of summer and tropical days in the Aegean Region (Erlat and Yavaşlı, 2011). In a study covering the Adana Sub-Region, which is also close to the study area, it was determined that the annual number of summer and tropical days showed positive anomaly values between 1993 and 2014 (Bayer Altın and Barak, 2017). In a study covering Beyşehir and Seydişehir stations included in the scope of this study, the total annual number of summer and tropical days in these two stations as of 1972-2011 period significant level increase trend has been identified (Kılıç, 2016). In the study conducted by Aykır (2017), a significant downward trend in the number of annual summer days in 
Isparta was determined. As can be seen, the study area and its surroundings were emphasized that the annual numbers of summer and tropical days and the annual number of tropical days have been increased. In only one study, the downward trend in the number of annual summer days in Isparta was noted.

As can be seen, research studies have been conducted on various scales, including the study area and its surroundings, including the annual number of summer and tropical days. However, there is no extensive research on the number of summer and tropical days in the Lakes District of Turkey. Therefore, this is considered as an important study in terms of eliminating the deficiency that has emerged.

This study aims to examine the long-term changes and trends of the annual number of summer and tropical days at the Lakes District of Turkey in the 1969-2014 period. In this sense, the question of "How did the long-term changes and trends the annual number of summer and tropical days at the Lakes District of Turkey evolve during the 1969-2014 period?" will be tried to be answered. In this regard, two sub-questions are determined. These are stated as "How did the long-term changes and trends the annual numbers of summer days at the Lakes District of Turkey evolve during the 1969-2014 period?" and "How did the long-term changes and trends the annual numbers of tropical days at the Lakes District of Turkey evolve during the 1969-2014 period?"

\section{LOCATION OF THE STUDY AREA}

The study area also covers the Lakes District of Turkey, is located within the borders of Antalya Sub-Region, the Mediterranean geographical region of Turkey. The study area is a transition area between the Mediterranean, Aegean, and Central Anatolia geographical regions (Figure 1). This area has large and small lakes, especially Beyşehir, Eğirdir, Burdur, and Acıgöl. The name of the Lakes District of Turkey also comes from these lakes. The study area includes Isparta and Burdur provincial centers, as well as settlements located within the borders of Isparta, Burdur, Antalya, Konya, and Afyonkarahisar provinces. This study is limited to 11 meteorological stations selected from the Lakes District of Turkey. The location of the stations is shown in Figure 1.

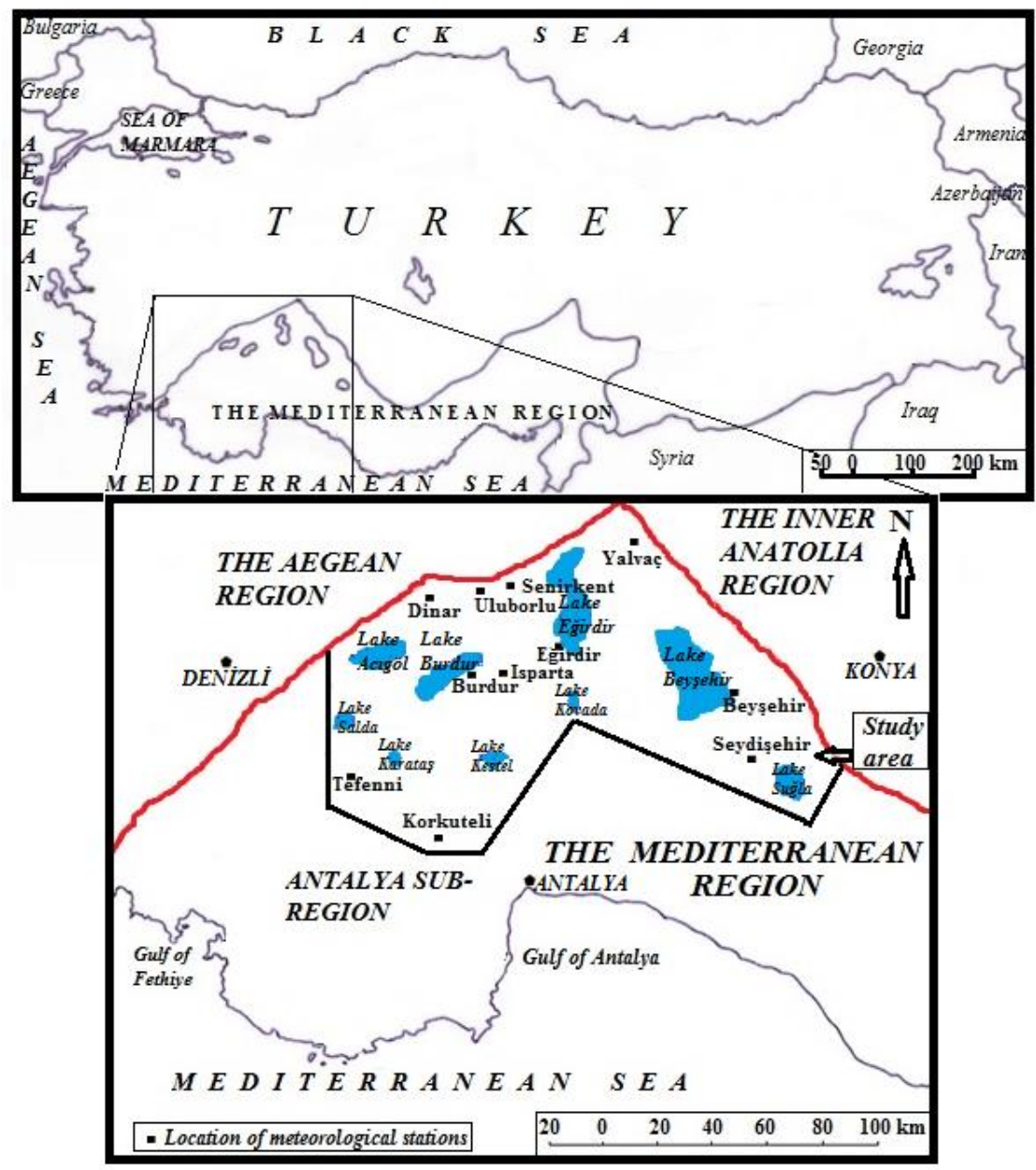

Figure 1: Location of the Study Area (taken and modified from Güçlü, 2015) 


\section{DATA AND METHODS}

\section{Data}

This study is limited to the daily maximum air temperature data sets between the period of $1969-2014$ of 11 meteorological stations selected from the Lakes District of Turkey (Some properties of meteorological stations are shown in Table 1). Data sets are provided by the General Directorate of Meteorology. Even though geographically they are located close to each other, the elevation values of the stations and the geographical characteristics of the sites in which they are located differ. For example, Beyşehir, Burdur, and Eğirdir are located on the edge of lakes called by their names, others on the plains. The station with the lowest elevation is Eğirdir $(920 \mathrm{~m})$ and the highest station is Tefenni (1142 m) (Table 1).

\begin{tabular}{|c|c|c|c|c|c|}
\hline $\begin{array}{l}\text { Meteorological } \\
\text { station }\end{array}$ & $\begin{array}{l}\text { Data } \\
\text { period }\end{array}$ & $\begin{array}{l}\text { Latitude } \\
\qquad\left(^{\circ}\right)\end{array}$ & $\begin{array}{l}\text { Longitude } \\
\quad\left({ }^{\circ}\right)\end{array}$ & $\begin{array}{c}\text { Elevation (m) } \\
\text { (above sea } \\
\text { level) }\end{array}$ & $\begin{array}{c}\text { Average air temperature }\left({ }^{\circ} \mathrm{C}\right)(1969-2014 \\
\text { period })\end{array}$ \\
\hline Korkuteli & $\begin{array}{l}1969- \\
2014\end{array}$ & 37,0565 & 30,1910 & 1017 & 12,6 \\
\hline Tefenni & $\begin{array}{l}1969- \\
2014\end{array}$ & 37,3161 & 29,7792 & 1142 & 11,9 \\
\hline Seydişehir & $\begin{array}{l}1969- \\
2014 \\
\end{array}$ & 37,4267 & 31,8490 & 1129 & 11,9 \\
\hline Beyşehir & $\begin{array}{l}1969- \\
2014\end{array}$ & 37,6777 & 31,7463 & 1141 & 10,9 \\
\hline Burdur & $\begin{array}{l}1969- \\
2014\end{array}$ & 37,7220 & 30,2940 & 957 & 13,3 \\
\hline Isparta & $\begin{array}{l}1969- \\
2014 \\
\end{array}$ & 37,7848 & 30,5679 & 997 & 12,2 \\
\hline Eğirdir & $\begin{array}{l}1969- \\
2014\end{array}$ & 37,8377 & 30,8720 & 920 & 12,7 \\
\hline Dinar & $\begin{array}{l}1969- \\
2014\end{array}$ & 38,0598 & 30,1531 & 864 & 12,9 \\
\hline Uluborlu & $\begin{array}{l}1969- \\
2014\end{array}$ & 38,0860 & 30,4582 & 1025 & 11,8 \\
\hline Senirkent & $\begin{array}{l}1969- \\
2014\end{array}$ & 38,1047 & 30,1910 & 959 & 12,6 \\
\hline Yalvaç & $\begin{array}{l}1969- \\
2014\end{array}$ & 38,2830 & 31,1778 & 1096 & 11,3 \\
\hline
\end{tabular}

\section{METHODS}

As it is aimed at this study to examine the long-term changes and trends in the annual number of summer and tropical days during the 1969-2014 period at the Lakes District of Turkey, the general screening model is used as the most suitable research model. The general screening model is one of the screening models that aim to describe a situation that exists in the past or still as it exists (Karasar, 2004). In this model, single or relational screening could be done (Karasar, 2004). In this study, a single screening model was used.

Within the scope of this research, the first stage of the meteorological stations in the study area was determined within the framework of the research question and sub-questions. The daily maximum air temperature data sets of these stations were provided by the General Directorate of Meteorology. In the second stage, the daily maximum air temperature data sets were checked, and 11 meteorological stations were selected covering the period of 1969-2014 and representing the general climatic characteristics of the study area. The locations of the stations are shown in Figure 1; some of them are shown in Table 1. In the third stage, the annual number of summer and tropical days of each meteorological station was determined. These data were transferred to tables using the Microsoft Excel 2010 program. At this stage, the annual number of summer and tropical days was processed into tables for each station and as the study area average. In addition, the annual numbers of summer and tropical days were detected in five periods. The data obtained in the fourth stage were transferred to the graphs. 5-year averages and trend lines were also shown in the graphs showing the number of annual summer and tropical days of each station. Mann-Kendall trend test was applied for the trend of annual numbers of summer days and tropical days. In the final stage, the results obtained were discussed with the results of other studies. The results of this research are presented below according to the research question and sub-questions. 


\section{RESULTS AND DISCUSSIONS}

\section{General Climatic Characteristics of the Study Area}

The study area is in the transition climate zone between the Mediterranean climate and the Central Anatolian continental climate in terms of geographical location (Atalay, 2010). Weather events and climate conditions of the Lakes District of Turkey is under the effect of general atmospheric circulation and weather systems affecting Turkey, as well as the district's physical geographical features (Erlat and Türkeş, 2013). The study area is affected by different air masses throughout the year. It is affected by tropical and polar air masses from September/October to March/April. It is affected by tropical air masses in the summer period. Depending on this, air temperatures vary by months and days. For example, in the periods when the effectiveness of the Azores anticyclone increases, warm weather conditions generally occur (Erlat and Türkeş, 2013).

During the 1969-2014 period, the annual average of air temperatures by selected meteorological stations from the Lakes District of Turkey show variations from $10,9^{\circ} \mathrm{C}$ (Beyşehir) and $13,3^{\circ} \mathrm{C}$ (Burdur) (Table 1). At any station, the monthly average air temperature value does not go below $0^{\circ} \mathrm{C}$ and does not exceed $25^{\circ} \mathrm{C}$. As well as throughout Turkey, monthly average air temperature values are lower in winter months, whereas it has higher values in summer months (Figure 2).

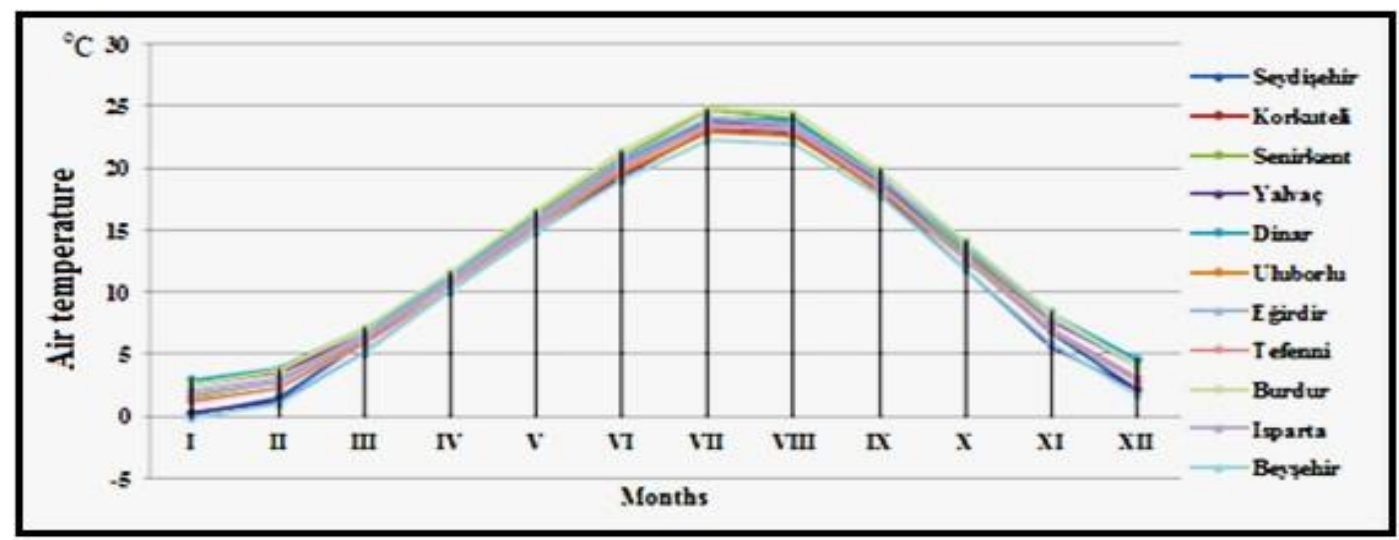

Figure 2: Monthly Average Air Temperature Values of the Meteorological Stations Selected from the Lakes District of Turkey between the Period of 1969-2014

Monthly average air temperatures ranged from $21,1^{\circ} \mathrm{C}$ (Beyşehir) to $23,2^{\circ} \mathrm{C}$ (Senirkent) in the summer season, when there is a high probability of appearing in summer and tropical days as of 1969-2014 period. In other words, monthly average air temperatures do not exceed $25^{\circ} \mathrm{C}$ in the summer season (Figure 2). On the other hand, monthly average air temperatures in the summer season showed values between $19^{\circ} \mathrm{C}$ (Beyşehir-June) and $24,8^{\circ} \mathrm{C}$ (Burdur-July) for the 1969-2014 period. Average temperature values ranged from $22,3^{\circ} \mathrm{C}$ (Beyşehir) to $24,8^{\circ} \mathrm{C}$ (Burdur) in July, where the highest air temperatures were observed during the year (Figure 2). Accordingly, the type of temperature regime, which is called continental transition type, is seen in the study area.

\section{Changes in the Annual Number of Summer and Tropical Days (1969-2014 Period)}

The average annual number of summer and tropical days was determined as 115,2 days at Lakes District of Turkey. The annual number of summer and tropical days ranged from 96,7 days (Beyşehir) to 128,7 days (Burdur) (Table 2). This result coincides with the result of the research conducted by Erlat and Yavaşlı (2009) that the number of summer days and tropical days varies according to the stations in the Aegean Region. On the other hand, these values are above the average of the study area in Beyşehir, Eğirdir, Isparta, Seydişehir, and Uluborlu (Figure 1; Table 2). The annual number of summer and tropical days numbers are below the average of the study area in Burdur, Dinar, Korkuteli, Senirkent, Tefenni and Yalvaç (located in the west of the study area) (Figure 1; Table 2). Accordingly, it can be said that the annual number of summer and tropical days is higher in the western part of the study area. 


\begin{tabular}{|c|c|c|c|c|c|c|c|}
\hline $\begin{array}{l}\text { Meteorological } \\
\text { station }\end{array}$ & $\begin{array}{l}\text { Annual Average } \\
\text { Number of Summer } \\
\text { and Tropical Days }\end{array}$ & $\begin{array}{l}\text { Annual } \\
\text { Average } \\
\text { Number of } \\
\text { Summer } \\
\text { Days }\end{array}$ & $\begin{array}{l}\text { The Highest } \\
\text { Annual } \\
\text { Number of } \\
\text { Summer Days } \\
\text { and Year }\end{array}$ & $\begin{array}{l}\text { The Lowest } \\
\text { Annual } \\
\text { Number of } \\
\text { Summer } \\
\text { Days and } \\
\text { Year }\end{array}$ & $\begin{array}{l}\text { Annual } \\
\text { Average } \\
\text { Number of } \\
\text { Tropical } \\
\text { Days }\end{array}$ & $\begin{array}{l}\text { The Highest } \\
\text { Annual Number } \\
\text { of Tropical Days } \\
\text { and Year }\end{array}$ & $\begin{array}{l}\text { The Lowest } \\
\text { Annual } \\
\text { Number of } \\
\text { Tropical Days } \\
\text { and Year }\end{array}$ \\
\hline Beyşehir & 96,7 & 71,6 & 97-1994 & $46-1986$ & 25,1 & $52-2007$ & $4-1976$ \\
\hline Burdur & 128,7 & 62,5 & $92-1976$ & $26-2008$ & 66,2 & $104-2008$ & 27-1976 \\
\hline Dinar & 126,5 & 64,7 & 93-1976 & $33-2008$ & 61,8 & $96-2008$ & 23-1976 \\
\hline Eğirdir & 97,4 & 67,5 & $92-1984$ & $36-2014$ & 27,4 & $60-2008$ & $5-1983$ \\
\hline Isparta & 114,5 & 68,3 & $94-1973$ & $44-2008$ & 46,2 & $79-2001$ & $14-1983$ \\
\hline Korkuteli & 126,3 & 66,8 & $103-1984$ & $37-2012$ & 59,5 & $106-2012$ & $20-1983$ \\
\hline Senirkent & 117,6 & 64,9 & 85-1997 & $34-2008$ & 52,9 & $95-2012$ & 18-1971 \\
\hline Seydişehir & 110,5 & 67,5 & 92-1984 & $36-2014$ & 43 & $72-2010$ & $11-1983$ \\
\hline Tefenni & 116,7 & 66 & 87-1973 & 39-2011 & 50,7 & $90-2012$ & $16-1983$ \\
\hline Uluborlu & 106,4 & 68,8 & $95-2003$ & $45-2008$ & 37,7 & $69-2008$ & $13-1983$ \\
\hline Yalvaç & 126,4 & 65,1 & 96-1976 & $34-2008$ & 61,3 & $95-2008$ & 23-1976 \\
\hline $\begin{array}{l}\text { Average of } \\
\text { study area }\end{array}$ & 115,2 & 66,7 & $87,9-1984$ & $43,8-2008$ & 48,3 & $80,2-2008$ & $17,5-1983$ \\
\hline
\end{tabular}

Five periods have been determined at selected meteorology stations to demonstrate the status of summer and tropical days in certain periods (Figure 3). Accordingly, although the duration varies, the total duration of summer days and tropical days generally increased (at all stations in the period 1980-2009) (Figure 3).

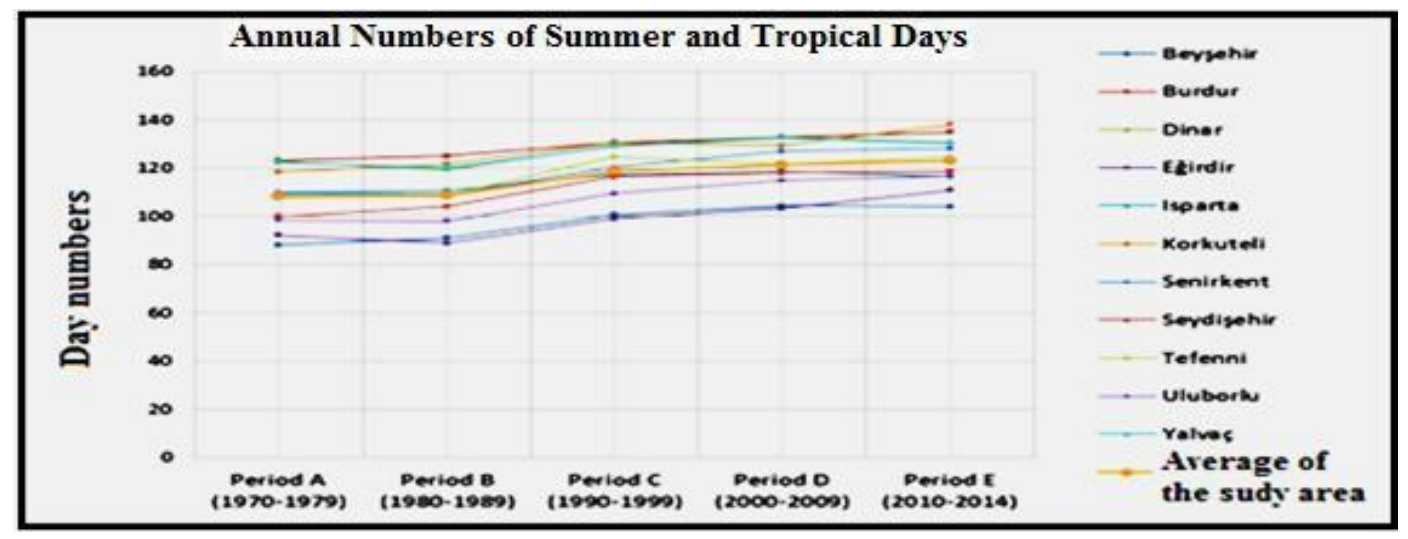

Figure 3: The Annual Numbers of Summer and Tropical Days According to Certain Periods in Meteorological Stations Selected from the Lakes District of Turkey between the Period of 1969-2014

In the meteorological stations selected from the study area, 5 periods were determined in order to reveal the situation of the annual number of summer and tropical days in certain periods. These periods were determined as the 1970-1979 (Period A), 1980-1989 (Period B), 1990-1999 (Period C), 2000-2009 (Period D) and 2010-2014 (Period E) (Figure 3).

Accordingly, the annual number of summer and tropical days has increased in general (in all stations between the period of 1980-1989 and 2000-2009) although it changes according to the periods at the Lakes District of Turkey varied (Figure 3). This result coincides with the result of the research conducted by IPCC (2013) that the number of summer days increased in parallel with the increase in air temperatures on a global scale (Aykır, 2017); with the result of the research conducted by Erlat and Yavaşlı (2011) that the annual summer and tropical day numbers has increased in the southern regions of the European continent during the last 30 years; with the result of the research conducted by Erlat and Türkeş (2013) that after the summer of 1975 as well as an overall upward trend in the annual number of summer days and tropical days; with the result of the research conducted by Erlat and Yavaşlı (2009) that there is an upward trend in the annual number of summer and tropical days in Aegean Region; with the result of the research conducted by Altın and Barak (2017) that the annual number of summer and tropical days shows positive anomaly values in Adana during 1993-2014; with the result of the research conducted by Kılıç (2016) that there is a statistically significant upward trend in the number of the annual total summer and tropical days in Beyşehir and Seydişehir during the period of 1972-2011.

In this regard, it shows that the days in which air temperatures exceeding $25^{\circ} \mathrm{C}$ are higher in almost every period. The number of days of air temperatures exceeding $25^{\circ} \mathrm{C}$ has increased almost every period in the study area as the 1969 - 
2014 period (Figure 3). It can be said that this situation is parallel to the change in air temperatures in the Mediterranean basin in the 1969-2014 period. The change in summer and tropical days by years is also related to the increase in air temperatures in the study area and anomalies in atmospheric circulation. For example, during periods when continental tropical air masses originating from northern Africa are introduced into the study area over the Mediterranean Sea, the daily maximum air temperatures rise and, accordingly, total numbers of summer day and tropical days are increasing.

\section{Changes in the Annual Number of Summer Days (1969-2014 Period)}

As of the selected meteorological stations, the average number of summer days at the Lakes District of Turkey was calculated as 66,7 days for the 1969-2014 period. The annual average number of summer days showed values ranging from 62,5 days (Burdur) to 71,6 days (Beyşehir) according to stations (Table 2). There are no spatially significant changes in the annual number of summer days. Annual numbers of summer days are higher than the average of the study area in Beyşehir, Eğirdir, Isparta, Korkuteli, Seydişehir, and Uluborlu; lower than the average of the study area in Burdur, Dinar, Senirkent, Tefenni and Yalvaç (Table 2). On the other hand, the annual average number of summer days showed a decrease in general from 1970-1979 to the 1980-1989 period, increased in 1990-1999, and then decreased in general (Figure 4).

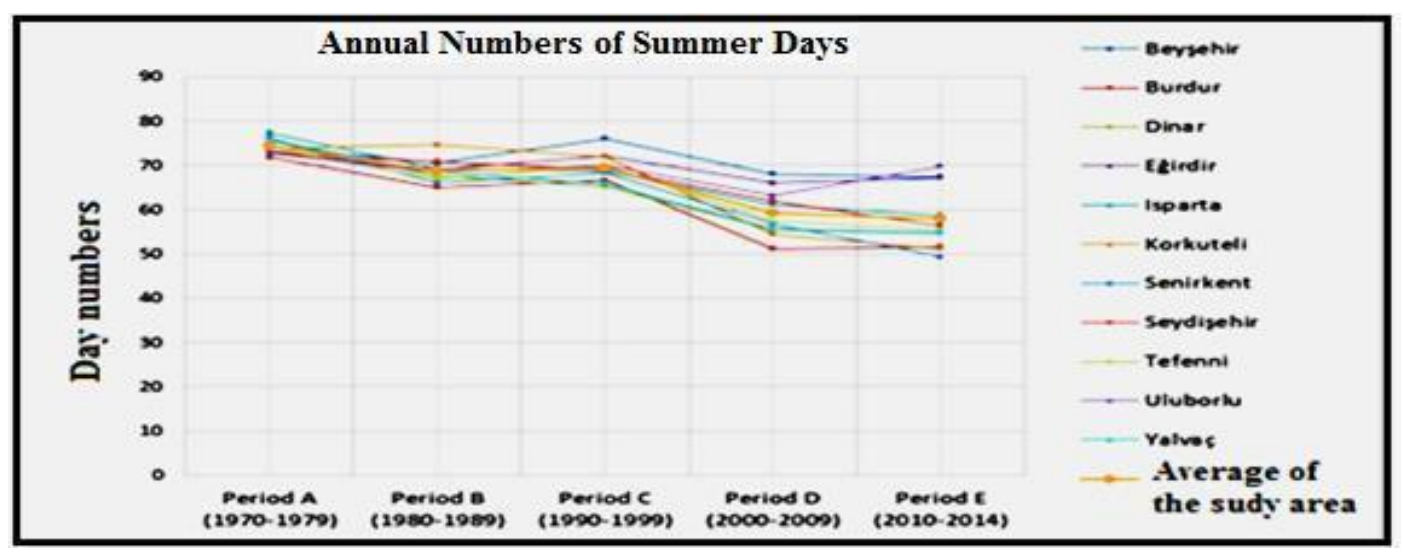

Figure 4: The Annual Numbers of Summer Days According to Certain Periods at Meteorological Stations Selected from the Lakes District of Turkey between the Period of 1969-2014

Looking at the trend line, it can be seen that it extends above the average in the period of 1969-1990 and below the average in the period of 1990-2014 (Figure 5). The trend line of the annual average number of summer days is shaped in the direction of decrease at the Lakes District of Turkey (Figure 5). According to the average of the study area, it is determined that the number of summer days shows a significant decrease trend (Kendall's tau value: $-0,350 ; p$ value: 0,001).

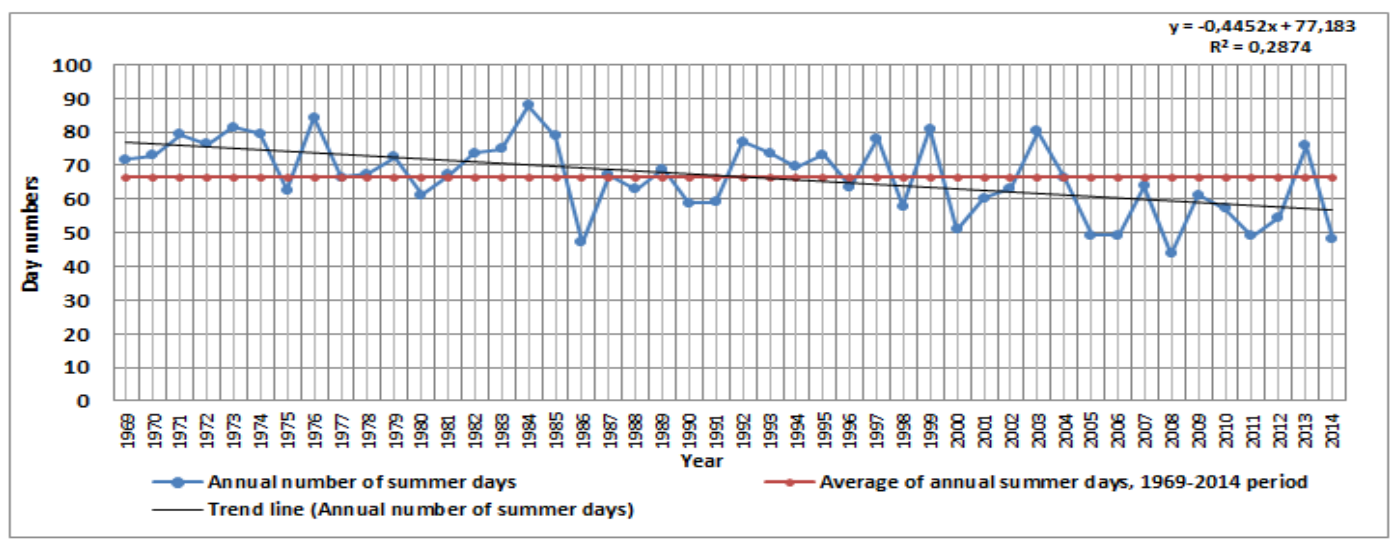

Figure 5: Trend in the annual number of summer days in the period 1969-2014 according to the average of 11 stations in the study area

This result coincides with the result of the research conducted by Acar Deniz (2013)'s stating that there is a general downward trend in the annual numbers of summer days in the western half of Turkey; with the result of the research 
conducted by Aykır (2017)'s stating that has seen a significant decline in annual summer days numbers in Isparta. On the other hand, this result differs from the result of the research conducted by IPCC (2013)'s stating that the increasing air temperature also causes an increase in the annual number of summer days at a global scale and in the European scale the annual number of summer days has increases for the last 30 years (Aykır, 2017); the result of the research conducted by Abbasnia and Toros (2018)'s stating that the annual numbers of summer days increased in Turkey from the year 1960 to the year 2010; the result of the research conducted by Giannakopoulos et al. (2009)'s stating that highlighted the increase in the annual number of summer days in the eastern part of the Mediterranean; the result of the research conducted by Sensoy et al. (2008)'s, by Şensoy et al. (2013)'s and by Abbasnia and Toros (2018)'s stating that in the 1960-2010 period to increase the annual number of summer days in Turkey; the result of the research conducted by Erlat and Türkeş (2013)'s stating that a significant increase in the annual number of summer days tend after 1975 in Turkey. This difference is thought due to the inclusion of tropical days in the number of summer days in related studies.

Looking at the trend line, it can be seen that it extends above the average in the period of 1969-1990 and below the average in the period of 1990-2014 (Figure 5). As mentioned above, the study area is located in the transition zone between the Mediterranean climate and Central Anatolia continental climate. The average elevation of meteorological stations selected from the study area is $1022 \mathrm{~m}$. For this reason, especially in the summer, when the continental tropical air mass is effective, the study area gets warmer during the daytime. This shows that the air temperatures measured during the daytime increase even more in the study area. This suggests that the air temperatures measured during the day in the study area are even higher. Accordingly, it could be stated that the possibility of experiencing tropical days is higher in the days of summer. Therefore, the probability of a tropical day rises in the days described as a summer day. The fact that the number of summer days tends to show a decrease in the study area (especially in the summer) shows that the air temperature rises rapidly throughout the day and rapidly reaches the tropical day values from the summer day values.

The years with the highest and lowest annual number of summer days are shown in Table 2. According to the selected meteorological stations, the years with the highest annual number of summer days was observed in Tefenni and Isparta in 1973; in Burdur, Dinar, Eğirdir, and Yalvaç in 1976; in Eğirdir and Korkuteli in 1984; in Beyşehir in 1994; in Senirkent in 1997 and in Uluborlu in 2003 (Table 2). 1986 in Beyşehir; 2008 in Burdur, Dinar, Isparta, Senirkent, Yalvaç, and Uluborlu; 2011 in Tefenni; 2012 in Korkuteli; 2014 in Eğirdir and Seydişehir are reported as the years, in which the lowest annual number of the summer days is observed (Table 2). As can be seen, variability is observed in the years when the annual number of summer days is the highest and the lowest. In this variability, it can be said that the geographical location of each station and anomalies in atmospheric circulation are effective.

The annual number of summer days by years during 1969-2014, the average of the 1969-2014 period, 5-year running average, and trend lines of selected 11 meteorological stations from the study area are separately shown in Figure 6. Accordingly, it could be seen that the number of summer days in all stations varies and decreases within years, and trend lines are shaped in the direction of a decrease in all stations. However, it is determined that the downward trend in Beyşehir (Figure 6a: Kendall's tau value: -0,126; $p$ value: 0,225), in Eğirdir (Figure 6d: Kendall's tau value: --0,202; $p$ value: 0,051$)$ ) and in Uluborlu (Figure 6j: Kendall's tau value: $-0,163$; $p$ value: 0,116 ) is not significant. A significant downward trend has been detected at other stations.

In parallel with the change in atmospheric circulation and global and regional temperatures affecting the study area in the annual number of summer days was determined a decrease in almost all stations in 1975, 1977, 1980, 1986, 1990, 1996, 1998, 2000, 2005, 2006, 2008 and 2014; an increase in almost all stations was determined in 1976, 1979, 1984, 1987, 1992, 1997, 1999, 2001, 2003, 2007, 2009 and 2013 (Figure 6). 

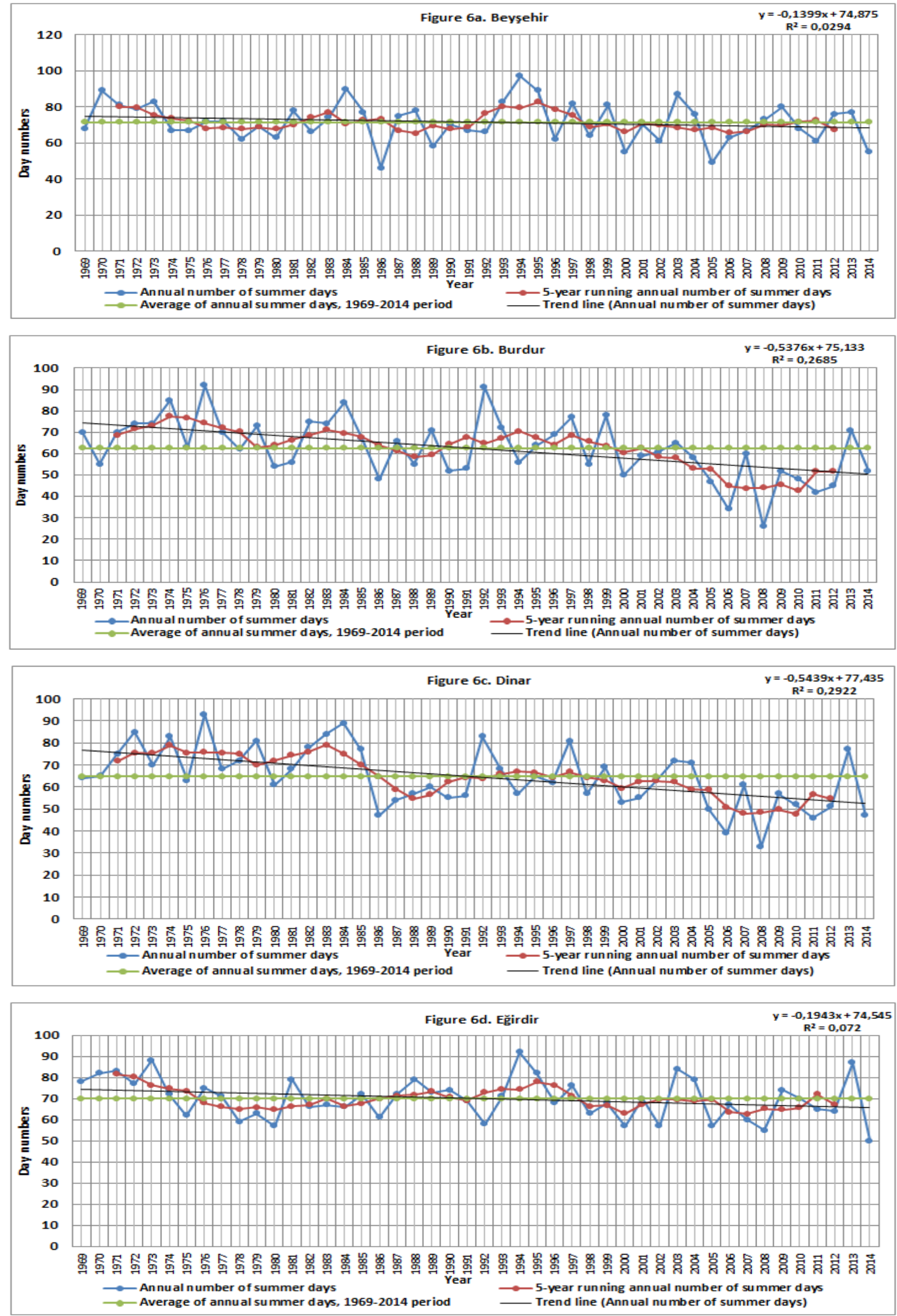

Figure 6 (6a, 6b, 6c, 6d): Trends in the Annual Number of Summer Days Between the Period of 1969-2014 for 11 Meteorological Stations in the Study Area 



Continuation of Figure $6(6 e, 6 f, 6 g, 6 h)$ 

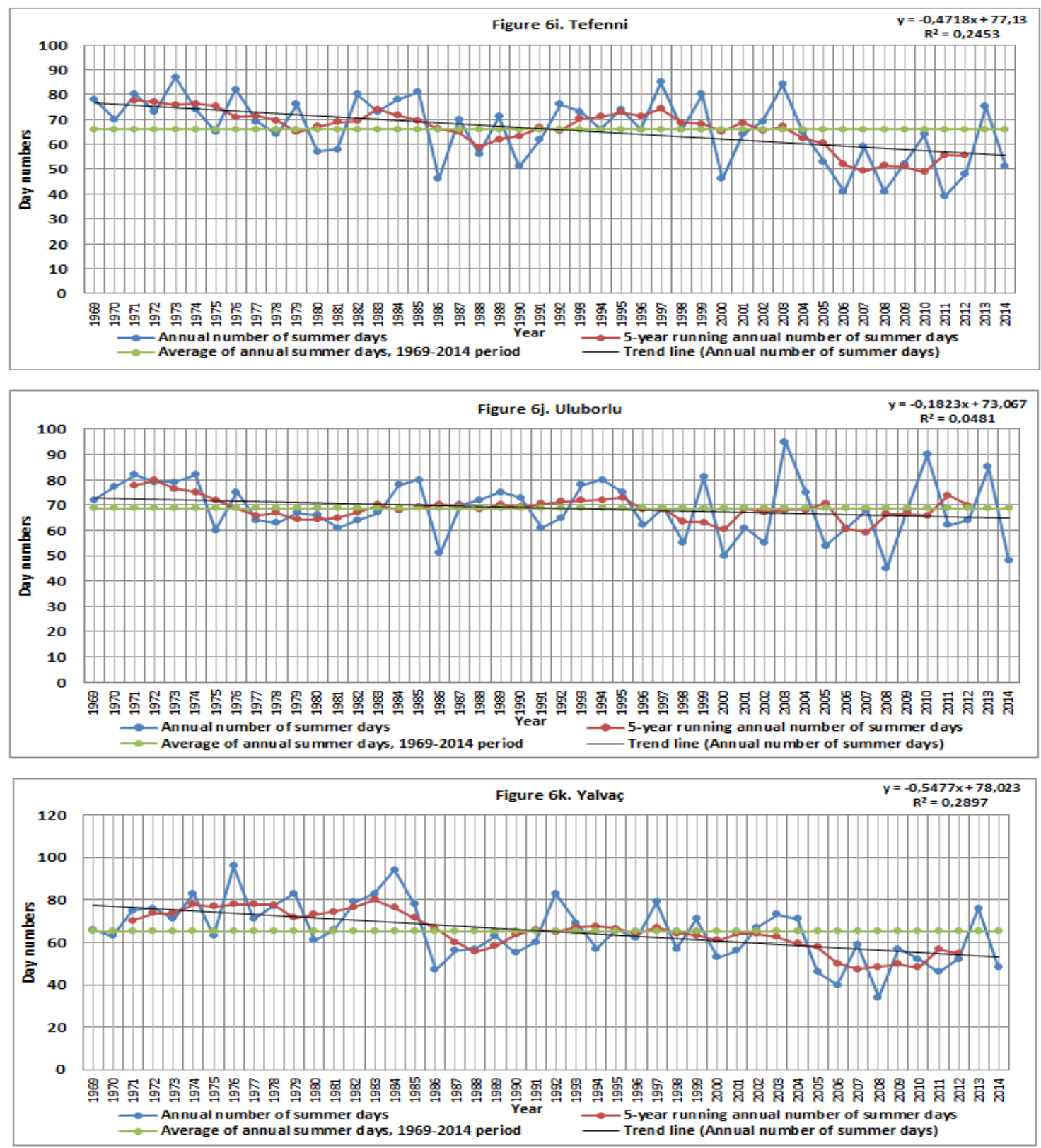

Continuation of Figure $6(6 \mathbf{i}, 6 \mathbf{j}, \mathbf{6 k})$

\section{Changes in the Annual Number of Tropical Days (1969-2014)}

At the Lakes District of Turkey, the average annual number of tropical days of 11 meteorological stations was calculated as 48,3 days. The annual number of tropical days showed variations from 25,1 days (Beyşehir) to 66,2 days (Burdur) according to the stations (Table 2). There are changes in the annual number of tropical days related to the geographical location of each station. On the other hand, the number of tropical days increased from 1970-1979 to 2000-2014 in the study area in general (Figure 7).

The years with the highest and lowest annual number of tropical days are shown in Table 2. The years with the highest annual number of tropical days were determined as 2001 in Isparta, 2007 in Beyşehir, 2008 in Burdur, Dinar, Eğirdir, Uluborlu and Yalvaç, 2010 in Seydişehir, 2012 in Korkuteli, Senirkent and Tefenni (Table 2). The lowest annual numbers of tropical days were determined as 1971 in Senirkent, 1976 in Beyşehir, Burdur, Dinar and Yalvaç, 1983 in Eğirdir, Isparta, Korkuteli, Seydişehir, Tefenni and Uluborlu (Table 2). As can be seen, the years in which the annual number of tropical days was the highest and lowest varied in the study area. It can be said that the geographical location of each station, urban heat island formations, and anomalies in the atmospheric circulation are effective in this change. 


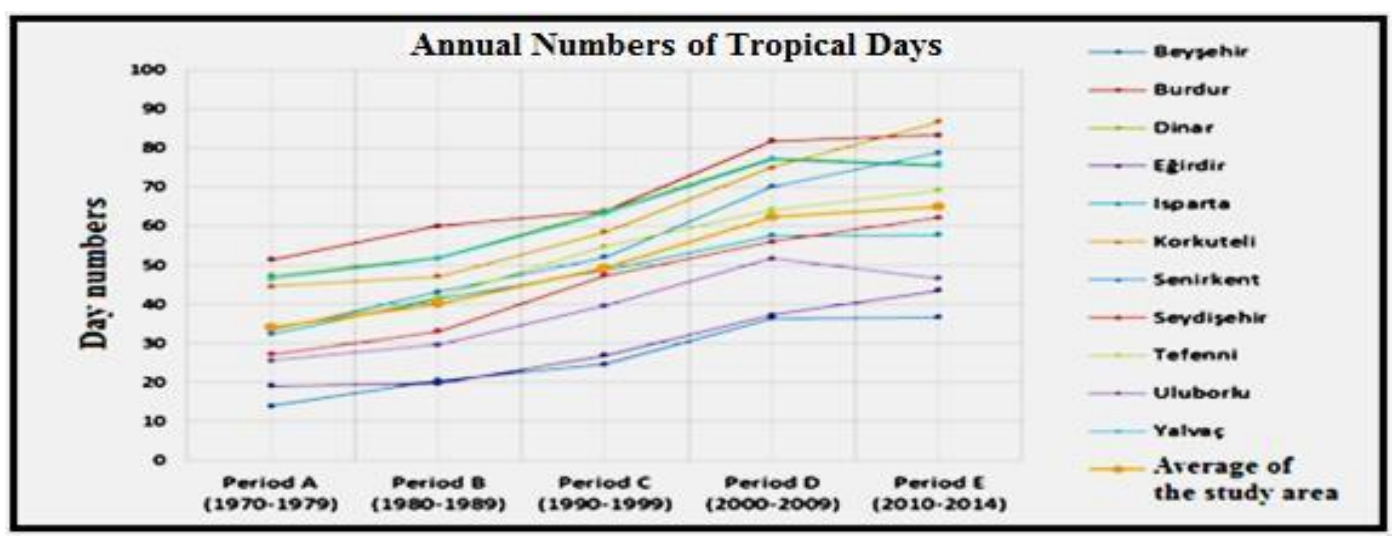

Figure 7: The Annual Numbers of Tropical Days According to Certain Periods of 11 Meteorological Stations for the Period 1969-2014

The trend line of the annual average number of tropical days is shaped in the direction of an increase in the Lakes District of Turkey (Figure 8). Looking at the trend line, it can be seen that it extends below the average in the period 1969-1990 and above the average in the period 1990-2014. According to the average of the study area, the number of tropical days showed a significant increase trend (Kendall's tau value: 0,$580 ; p$ value: $<0,0001$ ).

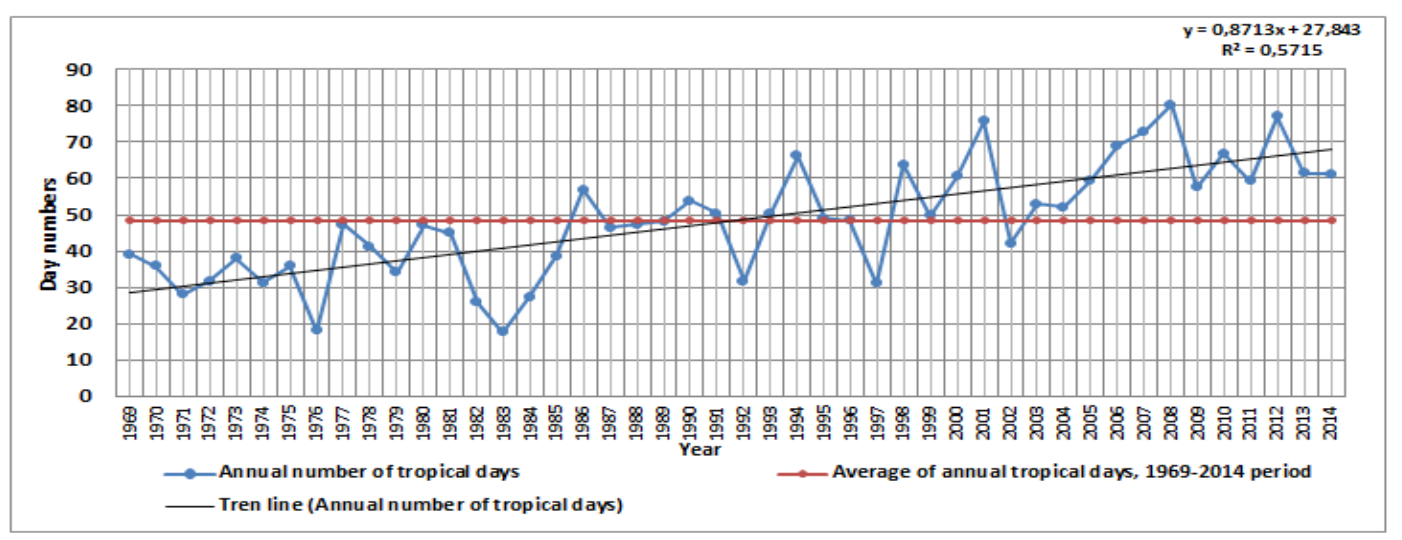

Figure 8: Trend in the Annual Number of Tropical Days in the Period 1969-2014 According to the Average of 11 Stations in the Study Area

This result coincides with the result of the research conducted by Kadığlu (2012) 's statement that the annual number of tropical days has increased significantly since 1990 across Turkey; with the result of the research conducted by Acar Deniz (2013) 's statement that there is a trend towards an increase in the number of tropical days in Turkey; with the result of the research conducted by Erlat and Türkeş (2013) 's statement that in the annual number of tropical days in Turkey has shown a significant upward trend after 1975; with the result of the research conducted by Erlat and Türkeş (2017) 's statement that the annual number of tropical days showed a strong upward trend after 1985 in Turkey. On the other hand, this indicates that air temperatures in the study area increase rapidly during the day, especially during summer, as stated in the evaluation section on the number of summer days, so the specific day changes rapidly from summer to tropical day. This is especially evident in summer when the continental tropical air mass is effective.

The annual number of tropical days by years between 1969 and 2014, the average of 1969-2014 period, 5-year running average, and trend lines of selected 11 meteorological stations from the study area are separately shown in Figure 9. Accordingly, it could be seen that the annual number of tropical days in all stations varies and increases within years, and trend lines are shaped in the direction of an increase in all stations. It is clearly seen from the formulas on the figures that the increase is evident (Figure 9). On the other hand, it was determined that the number of tropical days showed a significant increase trend in all stations (Kendall's tau values range from 0,423 (Isparta) to 0,647 (Senirkent). P value was determined as $<0,0001$ in all stations. 

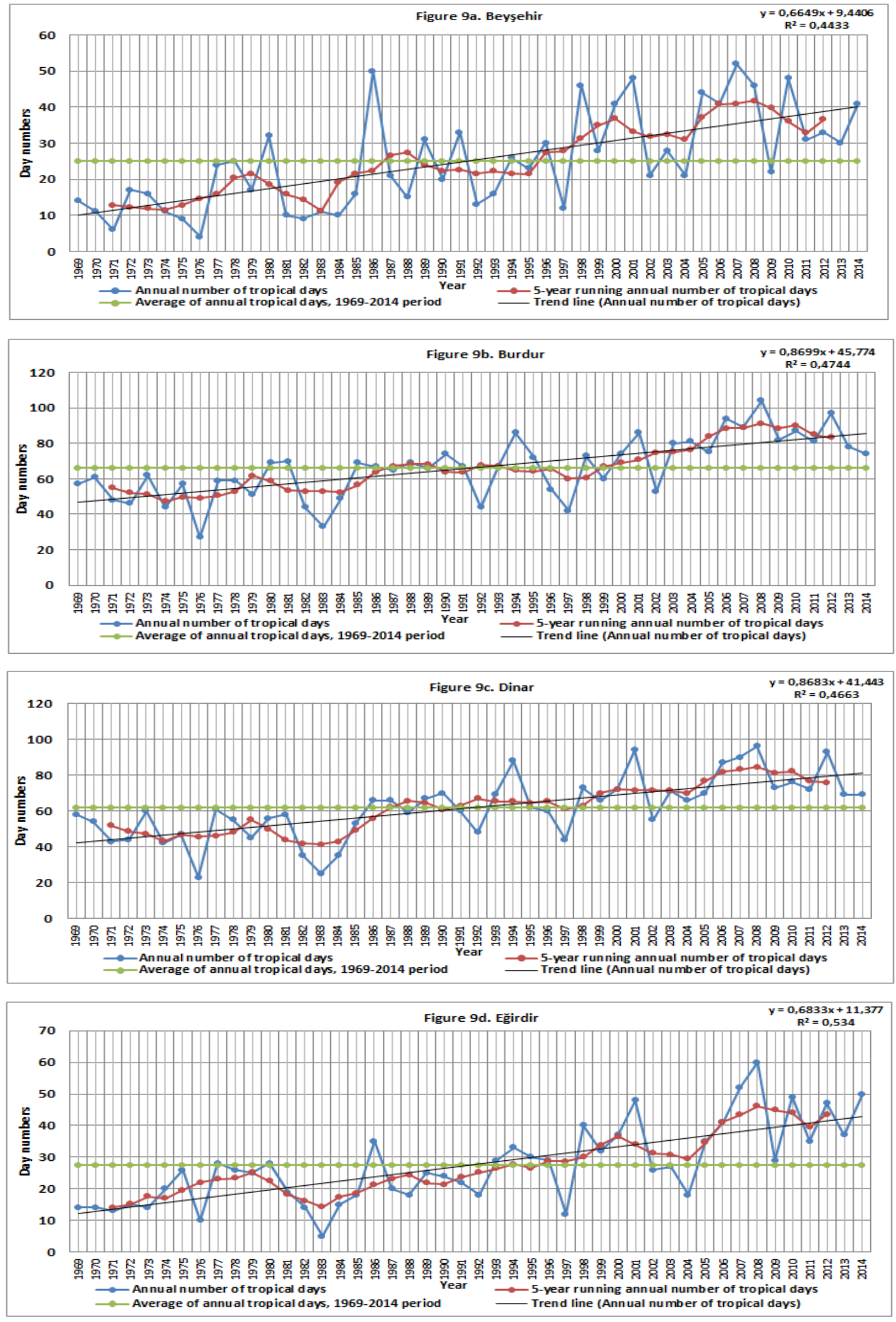

Figure 9 (9a, 9b, 9c, 9d). Trends in the annual number of tropical days in the period 1969-2014 for 11 meteorological stations in the study area 

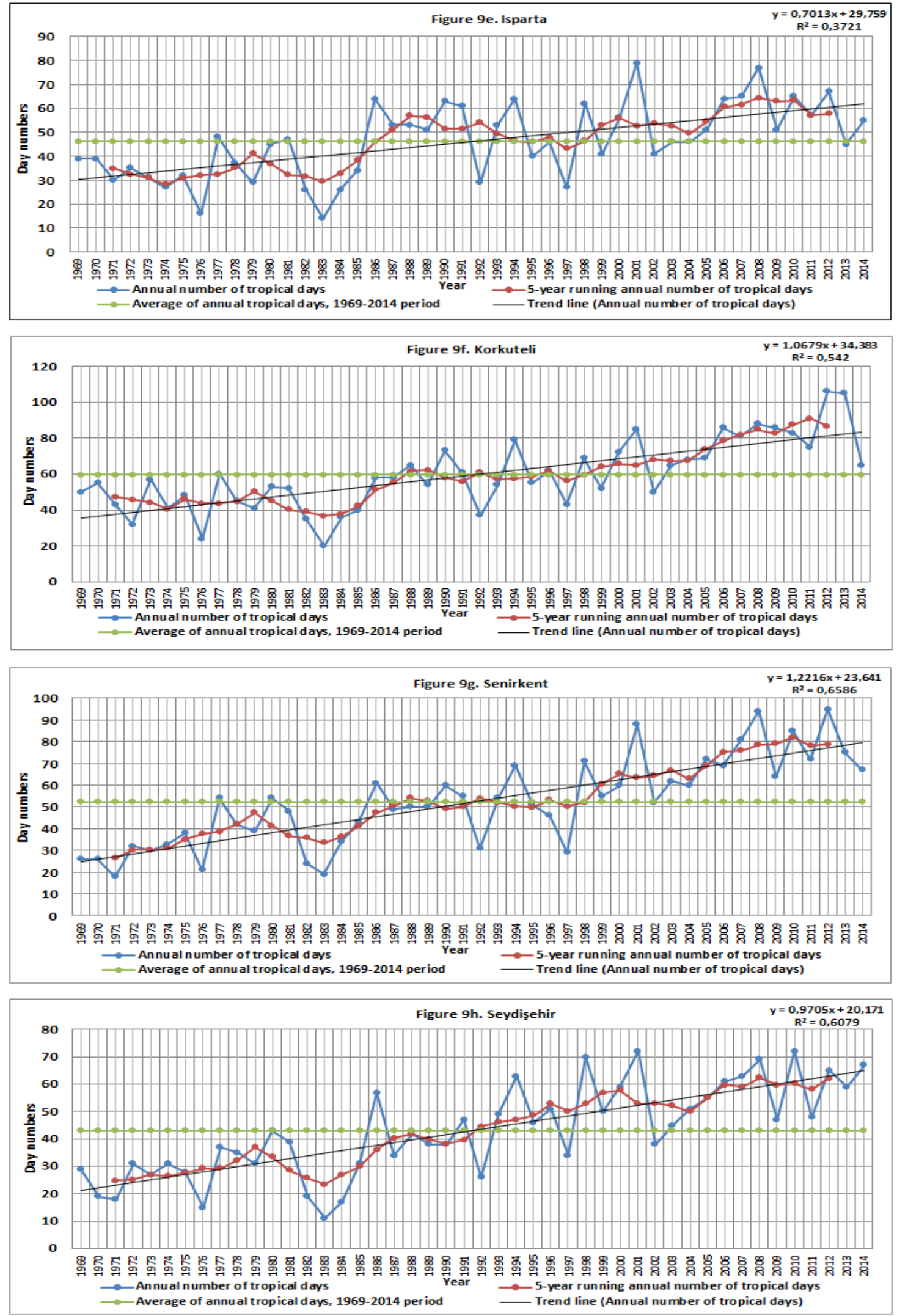

Continuation of Figure 9 (9e, 9f, 9g, 9h) 

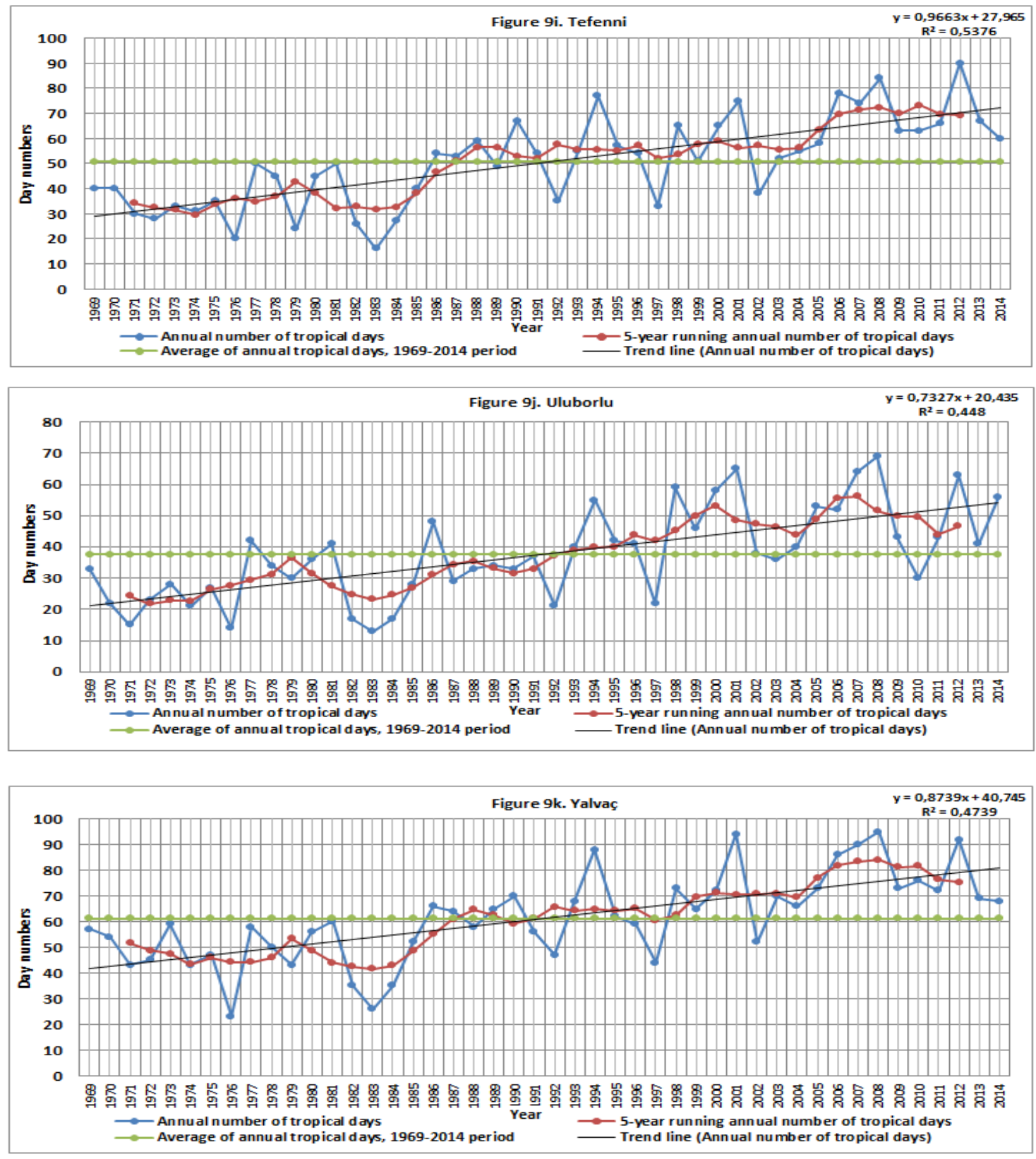

Continuation of Figure 9 (9i, 9j, 9k)

In parallel with the changes in atmospheric circulation and global and regional temperatures affecting the study area, the annual number of tropical days decreased in almost all stations in 1976, 1979, 1983, 1992, 1997, 1999, 2002, 2009, and 2011 (Figure 9). However, for the same reasons, the annual number of tropical days increased in almost all stations in 1977, 1986, 1994, 1998, 2001, 2008, and 2012 (Figure 9).

\section{CONCLUSIONS}

In this study, the long-term changes and trends of the annual number of summer and tropical days between the period of 1969-2014 in the Lakes District of Turkey by using the data of daily maximum air temperature of the selected 11 meteorological stations are examined. The study area, where the transition climate between the Mediterranean climate and Central Anatolia continental climate is effective, has a continental transition type temperature regime.

Summer and tropical days at the Lakes District of Turkey are often seen in summer months when the field is under the influence of tropical air masses. In summer, air temperatures rise rapidly during the daytime. It usually increases above $30^{\circ} \mathrm{C}$ on days when it exceeds $25^{\circ} \mathrm{C}$. Accordingly, the days covered by the summer day are likely to turn into tropical days. 
The average annual number of summer and tropical days was determined as 115,2 days at the Lakes District of Turkey. This value ranges from 96,7 days (Beyşehir) to 128,7 days (Burdur) according to meteorological stations. In this study, it was determined that the annual number of summer and tropical days at the Lakes District of Turkey was generally increased in the 1980-2009 period in all stations. The trend line of the average number of summer and tropical days is shaped in the direction of an increase in the study area.

The annual number of summer days ranges from 62,5 days (Burdur) to 71,6 days (Beyşehir) and the average of the study area was calculated as 66,7 days. As the selected meteorological stations the annual number of summer days is different. It can be said that the geographical location of each station and anomalies in the atmospheric circulation is effective in this difference. The number of summer days in the study area decreased in the 1980-2014 period in general. The trend line of summer day numbers is also shaped in the direction of a decrease in all stations. The number of summer days shows a decreasing trend that is not significant in Beyşehir, Eğirdir and Uluborlu stations, but significant in other stations and in the average of the study area.

In parallel with the change in atmospheric circulation and global and regional temperatures affecting the study area in annual number of summer days was determined a decrease in almost all stations in 1975, 1977, 1980, 1986, 1990, 1996, 1998, 2000, 2005, 2006, 2008 and 2014; increase in almost all stations in 1976, 1979, 1984, 1987, 1992, 1997, 1999, 2001, 2003, 2007, 2009 and 2013.

As of the 1969-2014 period, the average annual number of tropical days was calculated as 48,3 days at the Lakes District of Turkey. The annual number of tropical days ranged from 66,2 days (Burdur) to 25,1 days (Beyşehir) according to meteorological stations. It can be said that the geographical location of each station and anomalies in the atmospheric circulation is effective in this difference. On the other hand, the annual number of tropical days in all meteorological stations in the study area has generally increased and trend lines are shaped in the direction of increase in the 1969-2014 period. It was determined that the number of tropical days showed a significant increase trend in all stations and in the average of the study area.

In parallel with the change in atmospheric circulation and global and regional temperatures affecting the study area in the annual number of tropical days was determined a decrease in almost all stations in 1976, 1979, 1983, 1992, 1997, 1999, 2002, 2009 and 2011; increase in almost all stations was determined in 1977, 1986, 1994, 1998, 2001,2008 and 2012.

As a result, the annual number of summer days declined at the Lakes District of Turkey for the period 1969-2014. The annual number of tropical days and the annual number of summer and tropical days have increased. These results indicate an increase in the maximum daily air temperature in the study area.

\section{ACKNOWLEDGEMENTS}

This research did not receive any specific grant from funding agencies in the public, commercial, or not-for-profit sectors. The author is grateful to the Turkish State Meteorological Service for the meteorological data (daily maximum air temperature data set) of the stations.

\section{References}

Abbasnia, M. \& Toros, H. (2018). Analysis of long-term changes in extreme climatic indices: A case study of the Mediterranean climate, Marmara Region, Turkey. Pure and Applied Geophysics, 175 (11), 3861-3873.

Acar Deniz, Z. \& Gönençgil, B. (2015). Trends of summer daily maximum temperature extremes in Turkey. Phys. Geogr., 36(4), 268-281.

Acar Deniz, Z. \& Türkeş, M. (2011). Climatology of hot days of the 2010 summer in Turkey and analysis of its atmospheric causes. In: Proceedings of the National Geographical Congress with International Participation (CD-R), 7-10 September 2011, Turkish Geographical Society - İstanbul University.

Acar Deniz, Z. (2013). Türkiye'de yaz mevsimindeki sıcak günler ve sıcak günlerin eğilimleri (1970-2006) / Recent trends in observed hot days during summer season in Turkey (1970-2006). Türk Coğrafya Dergisi / Turkish Geography Journal, 61, 1-10.

Acar, Z., Gönençgil, B. \& Korucu Gümüşoğlu, N. (2018). Long-term changes in hot and cold extremes in Turkey. Coğrafya Dergisi / Journal of Geography, 37, 57-67.

Adams, R. M., Hurd, B. H., Lenhart, S. \& Leary, N. (1998). Effects of global climate change on agriculture: An interpretative review. Clim. Res. 11, 19-30. 
Alexander, L. V., Zhang, X., Peterson, T.C., Caesar, J., Gleason, B., Klein Tank, A.M.G., Haylock, M., Collins, D., Trewin, B., Rahimzadeh, F., Tagipour, A., Rupa Kumar, K., Revadekar, J., Griffiths, G., Vincent, L., Stephenson, D.B., Burn, J., Aguilar, E., Brunet, M., Taylor, M., New, M., Zha, P., Rusticucci, M. \& Vazquez Aguirre, J. L. (2006). Global observed changes in daily climate extremes of temperature and precipitation. J. Geophys. Res., 111, 1-22.

Alpert, P., Krichak, S.O., Shafir. H., Haim. D. \& Osetinsky, I. (2008). Climatic trends to extremes employing regional modelling and statistical interpretation over the E. Mediterranean. Global and Planetary Change, 63, 163-170.

Arseni-Papadimitriou, A. \& Maheras, P. (1991). Some statistical characteristics of air temperature variations at four Mediterranean stations. Theor Appl Climatol 43: 105-112.

Atalay, i. (2010). Uygulamalı Klimatoloji. İzmir: META Basım.

Aykır, D. (2017). Türkiye'de ekstrem sıcaklık indislerinin eğilimlerinde şehirleşmenin etkisi / Urbanization effect on trends of extreme temperature indices in Turkey. Türk Coğrafya Dergisi / Turkish Geography Journal, 69, 47-57.

Bayer Altın, T. \& Barak, B. (2017). Trends and changes in tropical and summer days at the Adana Sub-Region of the Mediterranean Region, southern Turkey. Atmospheric Research, 196: 182-199.

Caloiero, T. (2017). The trend of monthly temperature and daily extreme temperature during 1951-2012 in New Zealand. Theoretical and Applied Climatology, 129(1-2), 111-127.

Christensen J. H. \& Christensen O.B. (2007). A summary of the PRUDENCE model projections of changes in European climate by the end of this century. Climatic Change, 81, 7-30.

Çiçek, i. (2000). Türkiye'de termik dönemlerin yayılışı ve süreleri / Duration and the Dispertion of the Thermal Periods in Turkey). Ankara Üniversitesi Dil ve Tarih-Coğrafya Fakültesi Dergisi, Ankara University Journal of The Faculty of Languages and History-Geography, 40, 1-2, 189-212.

Diffenbaugh, N.S., Pal, J. S., Giorgi, F. \& Gao X. (2007). Heat stress intensification in the Mediterranean climate change hotspot. Geophysical Research Letters 34, L11706.

Dogan, M., Ulke, A. \& Cigizoglu, H. K. (2015). Trend direction changes of Turkish temperature series in the first half of the 1990s. Theoretical and Applied Climatology, 121(1-2), 23-39.

Dönmez, Y. (1984). Umumi Klimatoloji ve İklim Çalışmaları. İstanbul: Güryay Matbaacılık.

Erinç, S. (1984). Klimatoloji ve Metotları (3. Basım). İstanbul: Istanbul Üniversitesi Yayın No: 3278, Deniz Bilimleri ve Coğrafya Enstitüsü Yayın No: 2, Gür-Ay Matbaacılık.

Erlat, E. \& Türkeş, M. (2013). Observed changes and trends in numbers of summer and tropical days, and the 2010 hot summer in Turkey. International Journal of Climatology, 33: 1898-1908.

Erlat, E. \& Türkeş, M. (2017).Türkiye'de tropikal gece sayılarında gözlenen değişmeler ve eğilimler / Observed variations and trends in number of tropical nights in Turkey. Ege Coğrafya Dergisi / Aegean Geographical Journal, 26 (2), 95-106.

Erlat, E. \& Yavaşlı, D. D. (2009). Ege Bölgesinde tropikal günler ve yaz günlerinde gözlenen değişim ve eğilimler / Variation and trends in tropical and summer days at the Aegean Region of Turkey. Ege Coğrafya Dergisi / Aegean Geographical Journal, 18/ (1-2), 1-15.

Erlat, E. \& Yavaşlı, D. D. (2011). Ege Bölgesi'nde Sıcaklık Ekstremlerinde Gözlenen Değişim ve Eğilimlerin Değerlendirilmesi / Assessment of variability and trends in temperature extremes over Aegean Region of Turkey. Ankara Üniversitesi Çevrebilimleri Dergisi / Ankara University Journal of Environmental Sciences, 3(1), 25-37.

Erol, O. (1988). Genel Klimatoloji. İstanbul: Istanbul Üniversitesi Yayın No: 3526, Deniz Bilimleri ve Coğrafya Enstitüsü Yayın No:9, Final Ofset Matbaacilık ve Ambalaj Sanayi.

Giannakopoulos, C., Le Sager, P., Bindi, M., Moriondo, M., Kostopoulou, E. \& Goodess, C. M. (2009). Climatic changes and associated Impacts in the Mediterranean resulting from a $2{ }^{\circ} \mathrm{C}$ global warming. Global and Planetary Change, 68, $209-224$.

Giorgi, F. \& Lionello, P. (2008). Climate change projections for the Mediterranean region. Global and Planetary Change, 63, 90-104.

Gönençgil, B. \& Acar Deniz, Z. (2016). Extreme maximum and minimum air temperature in Mediterranean coasts in Turkey. Russian Geogr. Soc., 9, 59-70.

Güçlü, Y. (2015). Human thermal comfort situation in the Goller (Lakes) District of Turkey. Global Journal on Advances in Pure \& Applied Sciences. [Online], 07, 137-144.

Hansen, J., Ruedy, R., Sato, M. \& Lo, K. (2010). Global surface temperature change. Rev. Geophys. 48, RG4004. 1-29.

Hatfield, J.L. \& Prueger, J.H. (2015). Temperature extremes: effect on plant growth and development. In: Weather and Climate Extremes. 10. pp. 4-10.

Hertig, E., Seubert, S. \& Jacobeit, J.(2010). Temperature extremes in the Mediterranean area: trends in the past and assessments for the future. Nat. Hazards Earth Syst. Sci. 10, 2039-2050.

IPCC. (2014). Climate Change 2014: Impacts, Adaptation, and Vulnerability. Summaries, Frequently Asked Questions, and CrossChapter Boxes. A Contribution of Working Group II to the Fifth Assessment Report of the Intergovernmental Panel on Climate Change [Field, C.B., V.R. Barros, D.J. Dokken, K.J. Mach, M.D. Mastrandrea, T.E. Bilir, M. Chatterjee, K.L. Ebi, Y.O. Estrada, R.C. Genova, B. Girma, E.S. Kissel, A.N. Levy, S. MacCracken,P.R. Mastrandrea, \& L.L. White (eds.)]. World Meteorological Organization, Geneva, Switzerland, $190 \mathrm{pp}$.

Kadıoğlu, M. (1997). Trends in surface air temperature data over Turkey. Int. J. Climatol., 17, 511-520. 
Kadıoğlu, M. (2012). Türkiye'nin Birleşmiş Milletler iklim Değişikliği Çerçeve Sözleşmesi’ne iliş̧kin ikinci Ulusal Bildirimi Hazırlık Faaliyetlerinin Desteklenmesi Projesi: Türkiye'de Iklim Değişikliği Risk Yönetimi. Ankara: T.C. Çevre ve Şehircilik Bakanlığı.

Kadıoğlu, M., Şen, Z. \& Gültekin, L. (2001). Variations and trends in Turkish seasonal heating and cooling degree-days. Climatic Change, 49, 209-223.

Kang, Y., Khan, S. \& Ma, X. (2009). Climate change impacts on crop yield, crop water productivity and food security - a review. Prog. Nat. Sci., 19, 1665-1674.

Karabulut, M. (2012). Doğu Akdeniz'de ekstrem maksimum ve minimum sicakliklarin trend analizi / Analayzes of extreme maximum and minimum heats at the East Mediterranean. KSÜ Doğa Bil. Der., Özel Sayı/ KSU J. Nat. Sci. 37-44.

Karasar, N. (2004). Bilimsel Araştırma Metotları (13. Baskı), Ankara: Nobel Yayıncılık.

Kılıç, N. (2016). Analysis of precipitation-temperature records for many years in Konya. Master's dissertation, Selçuk University, Institute of Science, Agricultural Structures and Irrigation Department.

Klein Tank, A. \& Können, G.P. (2003). Trends in indices of daily temperature and precipitation extremes in Europe, 1946-1999, Journal of Climate 16, 3665-3680.

Kostopoulou, E. \& Jones, P.D. (2005). Assessment of climate extremes in the Eastern Mediterranean. Meteorology and Atmospheric Physics, 89, 69-85.

Kuglitsch, F.G., Toreti, A., Xoplaki, E., Della-Marta, P.M., Zerefos, C.S., Türkeş, M. \& Luterbacher, J. (2010). Heat wave changes in the Eastern Mediterranean since 1960. Geophys. Res. Lett., 37, L04802.

Lafta, A. M. \& Lorenzen, J.H. (1995). Effect of high temperature on plant growth and carbohydrate metabolism in potato. Plant Physiol., 109, 637-643.

Lelieveld, J., Hadjinicolaou, P., Kostopoulou, E., Chenoweth, J., El Maayar, M., Giannakopoulos, C., Hannides, C., Lange, M. A., Tanarhte, M., Tyrlis, E. \& Xoplaki, E. (2012). Climate change and ımpacts in the Eastern Mediterranean and the Middle East, Climatic Change, 114 (3-4), 667-687.

Nastos, P. T. \& Matzarakis, A. P. (2008). Variability of tropical days over Greece within the second half of the twentieth century. Theor. Appl. Climatol., 93: 75-89.

Şensoy, S., Alan, I. \& Demircan, M. (2008). Trends in Turkey climate extreme indices from 1971 to 2004. In: BALWOIS 2008, 1-9.

Şensoy, S., Türkoğlu, N., Akçakaya, A., Ekici, M., Demircan, M., Ulupınar, Y., Atay, H., Tüvan, A. \& Demirbaş, H. (2013). Trends in Turkey climate indices from 1960 to 2010. In: 6th Atmospheric Science Symposium ATMOS 2013, 1-8.

Simolo, C., Brunetti, M., Maugeri, M. \& Nanni, T. (2014). Increasingly warm summers in the Euro-Mediterranean zone: Mean temperatures and extremes. Reg. Environ. Chang., 14, 1825-1832.

Sütgibi, S. (2015). Büyük Menderes Havzasının sıcaklık, yağış ve akim değerlerindeki değişimler ve eğilimler/ Variations and trends in temperature, precipitation and stream-flow series in the Büyük Menderes River Basin, Marmara Coğrafya Dergisi / Marmara Geography Journal 31, 398-414.

Toros, H. (2012). Spatio-temporal variation of daily extreme temperatures over Turkey. Int. J. Climatol., 32 (7), $1047-1055$.

Türkes, M, Sümer, U.M. \& Demir, İ. (2002). Re-evaluation of trends and changes in mean, maximum and minimum temperatures of Turkey for the period 1929-1999. International Journal of Climatology 22, 947-977.

Türkeş, M. \& Altan, G. (2013). İklimsel değişimlerin ve orman yangınlarının Muğla Yöresindeki doğal çevre, doğa koruma alanları ve biyotaya etkilerinin bir ekolojik biyocoğrafya çözümlemesi / An ecological biogeography analysis of the ımpacts of climatic variations and forest fires on the natural environment, nature protection areas and biota in the Muğla District, Ege Coğrafya Dergisi / Aegean Geographical Journal, 22(2), 57-75.

Türkeş, M. \& Sümer, U.M. (2004). Spatial and temporal patterns of trends and variability in diurnal temperature ranges of Turkey. Theor. Appl. Climatol. 77, 195-227.

Türkeş, M. (1995). Türkiye'de yıllık ortalama hava sıcaklıklarındaki değişimlerin ve eğilimlerin iklim değişikliği açısından analizi. Çevre ve Mühendis 9, 9-15.

Türkeş, M. (2012). Türkiye'de gözlenen ve öngörülen iklim değişikliği, kuraklık ve çölleşme / Observed and projected climate change, drought and desertification in Turkey. Ankara Üniversitesi Çevre bilimleri Dergisi / Ankara University Journal of Environmental Sciences, 4 (2), 1-32.

Türkeş, M. (2013). İlim Verileri Kullanılarak Türkiye’nin Çölleşme Haritası Dokümanı Hazırlanması Raporu. Ankara: T.C. Orman ve Su İşleri Bakanlığı Çölleşme Ve Erozyonla Mücadele Genel Müdürlüğü.

Türkeş, M., Sumer, U.M. \& Kılıc, G. (1995). Variations and trends in annual mean air temperatures in Turkey with respect to climatic. Int. J. Climatol, 15, 557-571.

Türkeş, M., Utku, M.S. \& Kılıç, G. (1996). Observed changes in maximum and minimum temperatures in Turkey. Int. J. Climatol. 16, 463-477.

Xoplaki, E., Gonzalez-Rouco, J. F., Luterbacher, J. \& Wanner, H. (2003). Mediterranean summer air temperature variability and its connection to the large-scale atmospheric circulation and SSTs. Climate Dynamics 20: 723-739.

Zhang, X., Alexander, L., Hegerl, C.G., Jones, P., Tank, K. A., Peterson, C.T., Trewin, B. \& Zwiers, W.F. (2011). Indices for monitoring changes in extremes based on daily temperature and precipitation data. WIREs Clim Change, 2:851-870. 